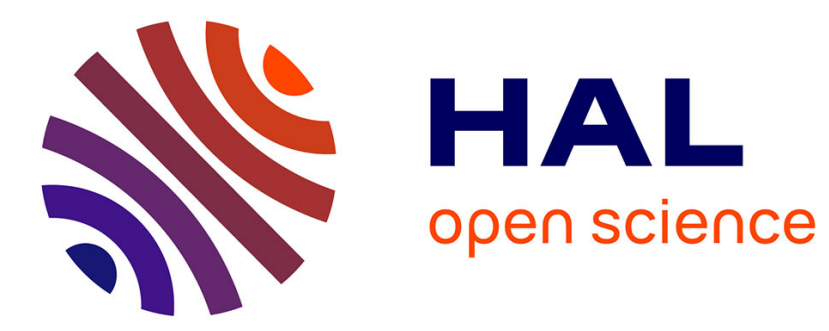

\title{
Administration of LHRH analogues in various ways: Effect on the advancement of spermiation in prespawning landlocked salmon, Salmo salar \\ Claudine Weil, L.W. Crim
}

\section{- To cite this version:}

Claudine Weil, L.W. Crim. Administration of LHRH analogues in various ways: Effect on the advancement of spermiation in prespawning landlocked salmon, Salmo salar. Aquaculture, 1983, 35, pp.103-115. 10.1016/0044-8486(83)90078-9 . hal-01604306

\section{HAL Id: hal-01604306 \\ https://hal.science/hal-01604306}

Submitted on 2 Jun 2020

HAL is a multi-disciplinary open access archive for the deposit and dissemination of scientific research documents, whether they are published or not. The documents may come from teaching and research institutions in France or abroad, or from public or private research centers.
L'archive ouverte pluridisciplinaire HAL, est destinée au dépôt et à la diffusion de documents scientifiques de niveau recherche, publiés ou non, émanant des établissements d'enseignement et de recherche français ou étrangers, des laboratoires publics ou privés.

\section{다(1)(2)}

Distributed under a Creative Commons Attribution - ShareAlikel 4.0 International 


\section{ADMINISTRATION OF LHRH ANALOGUES IN VARIOUS WAYS: EFFECT ON THE ADVANCEMENT OF SPERMIATION IN PRESPAWNING LANDLOCKED SALMON, SALMO SALAR}

\section{WEIL* and L.W. CRIM}

Marine Sciences Research Laboratory, Memorial University of Newfoundland, St. John's, Nfld. A1C 5S7 (Canada)

*Present adress: Laboratoire de Physiologies des Poissons, INRA, 78350 Jouy en Josas (France)

(Accepted 4 January 1983)

\section{ABSTRACT}

Weil, C. and Crim, L.W., 1983. Administration of LHRH analogues in various ways: effect on the advancement of spermiation in prespawning landlocked salmon, Salmo salar. Aquaculture, 35: 103-115.

During an experimental period of 12 days, the onset of spermiation, quantity of collectable milt, spermatocrit, plasma and pituitary gonadotropin hormone (GtH) were compared in control and LHRH analogue (LHRHa)-treated prespawning landlocked salmon. Des-Gly ${ }^{10}-\left[D-A l a^{6}\right]-$ LHRH ethylamide (D-Ala ${ }^{6}-\mathrm{LHRH}$ EA) was administered either by intraperitoneal multiple injections in saline or $40 \%$ propylene glycol or by a single intraperitoneal implant in silicone rubber. [6-(D-2-naphthylalanine)] LHRH (D-Nal $(2)^{6}-\mathrm{LHRH}$ ) was administered in a single cholesterol pellet. All the methods of administering LHRHa effectively accelerated the onset of spermiation and increased the volume of collectable milt. Study of the spermatocrit indicated that this increase is associated with an advancement in the production of spermatozoa and is not just due to sperm dilution. Furthermore, this increase in milt volume is related to an increase in plasma GtH. On the other hand, LHRHa treatments did not provoke any change in pituitary GtH content.

\section{INTRODUCTION}

It is now established that teleost fish have a gonadotropin releasing hormone (for a review see Ball, 1981). Although the structure is different from mammalian GnRH (King and Millar, 1980; Barnett et al., 1982; Idler and Crim, 1982), synthetic LHRH and some agonist analogues are effective in inducing GtH secretion in fish and some trials have been conducted to test these peptides as spawning agents (review by Lam, 1982). Because high doses of LHRH are required in fish in comparison with mammals, different methods have been tried to maximize the peptide potency. Some investiga- 
tions compared different ways of administration of LHRH: intracranial versus intraperitoneal or intramuscular injection (Anon., 1975 in female chinese carp; Lam et al., 1976 in female goldfish; Sokolowska et al., 1978 in female common carp); intraperitoneal versus intramuscular injection (Donaldson et al., 1981 in female coho salmon). Other authors compared different vehicles (saline solution or complete adjuvant: Aida et al., 1978 in female plaice and goby). Some authors have tried to use superactive LHRH analogues (LHRHa) which are of greater potency in mammals. In fish, desGly $^{10}$-[D-Ala $\left.{ }^{6}\right]$-LHRH ethylamide (D-Ala ${ }^{6}$-LHRH EA) was shown to be more potent than LHRH since the minimum effective dose to induce ovulation in grass carp was approximately 100 times lower than that of the decapeptide (Anon, 1977a). Furthermore, this analogue may cause an increase in plasma $\mathrm{GtH}$ which is of longer duration than that caused by LHRH (Peter, 1980 in male goldfish; Van der Kraak et al., 1982 in female coho salmon). Another analogue, D-Ser ${ }^{6}$-LHRH ethylamide, was used as a primer to induce spawning in carp and induced as well a prolonged GtH release compared to LHRH (Breton et al., 1983). To maximize the biological effectiveness of analogues, attempts were made to administer the hormone in slow release vehicles such as oil (Anon, 1977b in female grass carp), propylene glycol (Takashima et al., personal communication, 1981 in male common carp), or a cholesterol pellet (Crim et al., 1982 in male and female landlocked salmon).

As these analogues are more potent than LHRH, their cost of use is lower. For this reason, two LHRH analogues were used in the present work and we tried to find a practical way of administration, maximizing their biological effectiveness and minimizing frequent handling of the fish. For this purpose, we compared the effectiveness of LHRHa administered either by intraperitoneal injection in liquid vehicles (saline or propylene glycol) or by implant (silicone rubber or cholesterol pellet). The biological test used was the induction of spermiation in prespawning landlocked salmon. Spermiation, characterized by the percentage of spermiating fish, by the volume of collectable milt released by hand-stripping and by spermatocrit, was related to plasma and pituitary gonadotropin $(\mathrm{GtH})$ profiles.

\section{MATERIALS AND METHODS}

The experiment was performed in October 1981 with a laboratory stock of 2-year-old, adult, prespawning landlocked salmon (Salmo salar), weighing $92.3 \pm 5.1 \mathrm{~g}$, maintained in ambient freshwater and exposed to a simulated natural photoperiod. Fish at the end of spermatogenesis but not yet spermiating at the beginning of the experiment were distributed in six groups. Five groups, each of 6 or 7 individuals, were treated with LHRHa administered by intraperitoneal injection or by intraperitoneal implant. The experiment lasted twelve days (day 1 to day 12).

(1) Intraperitoneal (I-P) injections: des-Gly ${ }^{10}-\left[\mathrm{D}-\mathrm{Ala}^{6}\right]-\mathrm{LHRH}$ ethylamide 
(D-Ala ${ }^{6}$-LHRH EA) (Sigma, batch 100F-0608) was administered to three groups at the same total dose $(0.750 \mathrm{mg} / \mathrm{kg}$ body weight) but the vehicles used, the dosage and the number of injections differed:

Saline group $\left(S a_{1}\right)$. Six injections of $125 \mu \mathrm{g} / \mathrm{kg}$ body weight of the analogue dissolved in Cortland's saline (Wolf, 1963) were given one every two days (days $1,3,5,7,9,11$ ), to six individuals.

Saline group $\left(\mathrm{Sa}_{2}\right)$. The vehicle was the same saline solution. Two injections of $62.5 \mu \mathrm{g} / \mathrm{kg}$ body weight given $6 \mathrm{~h}$ apart were administered every two days (days $1,3,5,7,9,11$ ) to six individuals.

Polypropylene glycol group $(\mathrm{Pg})$. An injection of the analogue dissolved in $40 \%$ propylene glycol was administered on days 1 and 7 to seven fish at the dosage of $0.375 \mu \mathrm{g} / \mathrm{kg}$ body weight.

(2) Intraperitoneal (I-P) implants: Implants surgically inserted in the perivisceral cavity as previously described (Crim et al., 1982) were administered to two groups.

Silicone rubber group (Si). $156 \mu \mathrm{g}$ of des-Gly ${ }^{10} \cdot\left[\mathrm{D}-\mathrm{Ala}^{6}\right]$-LHRH ethylamide (Sigma, batch 100F-0608) corresponding to a dose of $1.6 \mathrm{mg} / \mathrm{kg}$ body weight were administered to seven fish on day 1 in a single silicone rubber implant (Medical Elastomer 382 - Dow Corning) according to the method described by Lotz and Syllwasschy (1979).

Cholesterol pellet group (Ch). Cholesterol pellets containing $25 \mu \mathrm{g}$ of [6(D-2-naphthylalanine)] LHRH (Syntex Inc.) corresponding to a dose of $270 \mu \mathrm{g} / \mathrm{kg}$ body weight were administered to seven fish on day 1 . This LHRH analogue is approximately 200 times more potent than LHRH in vivo in rats (Nestor et al., 1982). All the LHRHa treatments were adminisstered under anesthesia in phenoxyethanol $(0.5 \mathrm{ml} / \mathrm{l})$.

The six th group, used as a control group (group C) was composed of seven intact individuals (no sham injection or implantation).

In order to have the same stressful situation in all six groups, all the fish were anesthetized every two days when LHRHa treatment was given to group $\mathrm{Sa}_{1}$. Only group $\mathrm{Sa}_{2}$ was anesthetized twice a day when LHRHa was administered. In all six groups the following parameters were monitored after anesthesia in phenoxyethanol:

- spermiation characterized by the percentage of spermiating fish, by the volume of collectable milt released by hand-stripping and by spermatocrit. These parameters were measured on days $2,4,6,8,10,12$. Spermatocrit was measured in $0.1 \mathrm{ml}$ capillaries after centrifugation at $12000 \mathrm{rpm}$ for $20 \mathrm{~min}$. - plasma GtH determined from blood samples $(200 \mu \mathrm{l})$ taken from the caudal vasculature with an heparinized syringe (heparin Cortland's 29 units/ $\mathrm{ml}$ ) on days $2,6,8,10,12$ at the same time in the morning.

- pituitary GtH concentrations measured on day 12. Pituitary samples were taken at the same time in the morning.

Plasma and pituitary GtH were determined by radioimmunoassay (Crim et al., 1975).

LHRHa treatments and sampling schedules are summarized in Table I. 


\section{TABLE I}

LHRHa treatments and sampling schedules during the 12-day experimental period. $\downarrow$ Administration of LHRHa treatments. Groups $\mathrm{Sa}_{1}, \mathrm{Sa}_{2}, \mathrm{Pg}$ (I.P. injection). Groups Si and Ch (I.P. implant). See Materials and Methods for details of treatments. (1), (2), (3) refer to milt, plasma and pituitary sampling, respectively

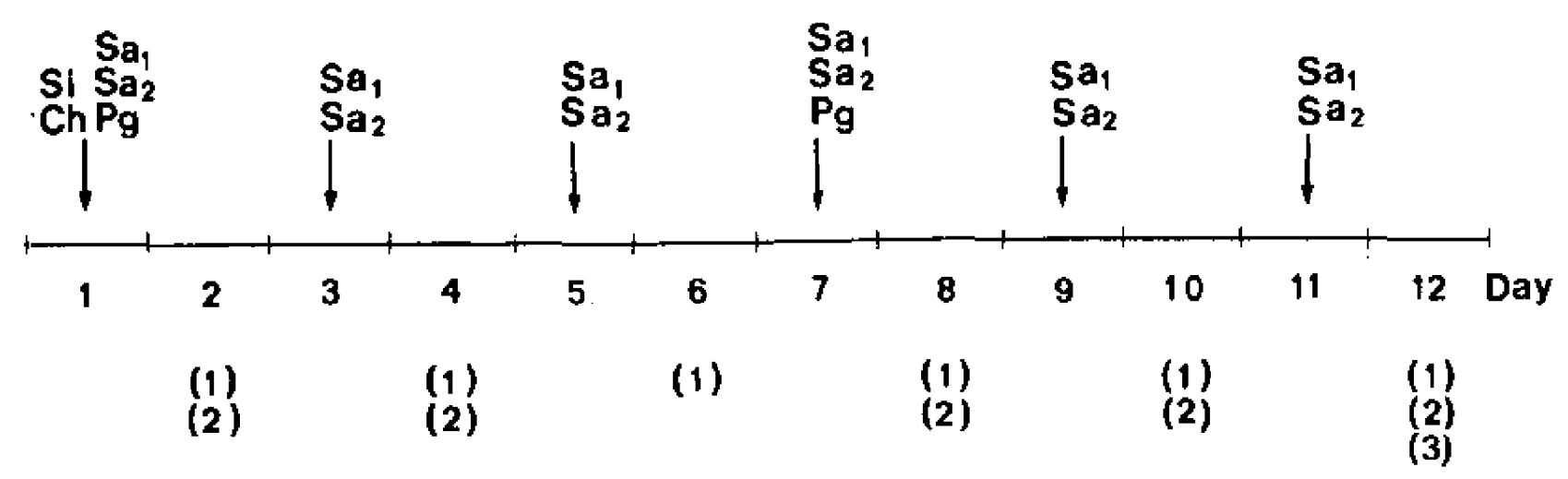

The Mann Whitney $U$ test was used to compare the mean of the different experimental groups at the same sampling time. Analysis of variance and Duncan's multiple range test at $P<0.05$ were used to determine the differences between the values of the same experimental group at different sampling times.

\section{RESULTS}

\section{Spermiation characteristics (Table II)}

All five LHRHa treatments accelerated the onset of spermiation in comparison with controls. In groups $\mathrm{Sa}_{1}, \mathrm{Sa}_{2}, \mathrm{Si}$ and $\mathrm{Ch}$ spermiation began on day 2, i.e., 6 days earlier than the control. After treatment with LHRHa in $40 \%$ propylene glycol (group Pg) spermiation occurred 4 days earlier (day 4). At the beginning of spermiation the volume of collectable milt was too low for spermatocrit measurement. By day $8,100 \%$ of the fish were spermiating after LHRHa administration in saline (groups $\mathrm{Sa}_{1}$ and $\mathrm{Sa}_{2}$ ) or in cholesterol implant (group $\mathrm{Ch}$ ). On this same day the initiation of spermiation was noticed in the control group. By the end of the experiment all the LHRHatreated fish were spermiating, whereas only $75 \%$ were spermiating in the control group. During the experimental period collectable milt volume and spermatocrit were very heterogeneous in all six groups. As a consequence of this heterogeneity, throughout the six samplings of the experimental period, no significant change in these two parameters could be noticed in any of the six groups. However, looking at the individual values, it appeared that in control and treated fish collectable milt volume and spermatocrit are lower at the beginning of spermiation and higher on day 12.

No significant differences in collectable milt volume and spermatocrit could be detected at each sampling between groups $\mathrm{Sa}_{1}, \mathrm{Sa}_{2}, \mathrm{Si}$ and $\mathrm{Ch}$ in which the beginning of spermiation was noticed on the same day (day 2). 


\section{TABLE II}

The influence of LHRHa treatments on the spermiation response in male landlocked salmon

Treatment Days of experiment groups

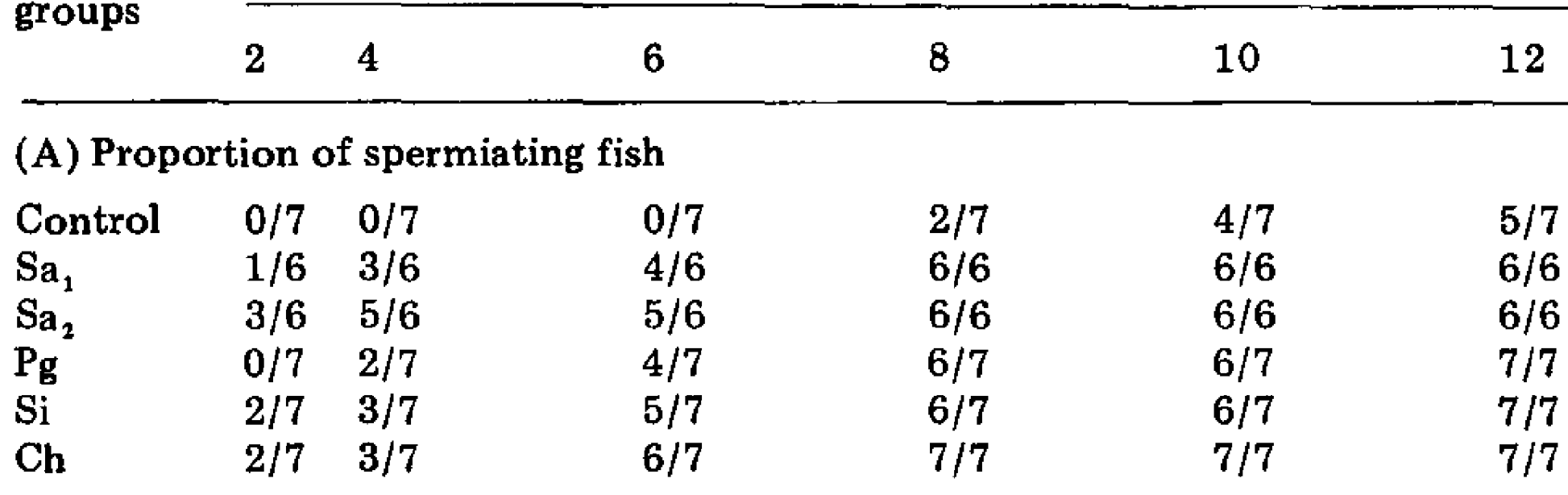

(A) Proportion of spermiating fish

(B) Collectable milt volume ( $\mu 1 / \mathrm{g}$ body weight) ${ }^{\mathrm{a}}$

\begin{tabular}{|c|c|c|c|c|c|c|}
\hline Control & & & & 0.79 & $\begin{array}{l}0.79 \\
(021-108)\end{array}$ & $\begin{array}{l}0.91 \\
(0.65-1.47)\end{array}$ \\
\hline $\mathrm{Sa}_{1}$ & $\epsilon$ & $\begin{array}{l}1.31 \\
(0.52-2.56)\end{array}$ & $\begin{array}{l}2.24 \\
(1.34-3.08)\end{array}$ & $\begin{array}{l}2.62 \\
(0.43-4.92)\end{array}$ & $\begin{array}{l}2.61 \\
(0.83-4.07)\end{array}$ & $\begin{array}{l}2.77 \\
(0.99-3.90)\end{array}$ \\
\hline $\mathrm{Sa}_{2}$ & $\epsilon$ & $\begin{array}{l}0.63 \\
(0.11-2.25)\end{array}$ & $\begin{array}{l}2.48 \\
(0.77-5.55)\end{array}$ & $\begin{array}{l}3.67 \\
(1.03-6.31)\end{array}$ & $\begin{array}{l}3.60 \\
(1.54-5.40)\end{array}$ & $\begin{array}{l}3.38 \\
(2.72-5.55)\end{array}$ \\
\hline $\mathbf{P g}$ & & $\epsilon$ & $\begin{array}{l}1.85 \\
(1.46-2.25)\end{array}$ & $\begin{array}{l}1.12 \\
(0.16-3.31)\end{array}$ & $\begin{array}{l}2.07 \\
(1.25-3.27)\end{array}$ & $\begin{array}{l}1.65 \\
(0.14-7.07)\end{array}$ \\
\hline $\mathrm{Si}$ & $\epsilon$ & $\begin{array}{l}0.35 \\
(0.07-0.56)\end{array}$ & $\begin{array}{l}1.53 \\
(0.19-4.56)\end{array}$ & $\begin{array}{l}3.35 \\
(1.88-5.70)\end{array}$ & $\begin{array}{l}2.75 \\
(0.99-5.04)\end{array}$ & $\begin{array}{l}1.73 \\
(0.95-3.53)\end{array}$ \\
\hline $\mathrm{Ch}$ & $\epsilon$ & $\begin{array}{l}1.95 \\
(1.10-2.25)\end{array}$ & $\begin{array}{l}2.19 \\
(0.16-5.01)\end{array}$ & $\begin{array}{l}1.71 \\
(0.22-3.49)\end{array}$ & $\begin{array}{l}3.44 \\
(0.03-11.63)\end{array}$ & $\begin{array}{l}2.33 \\
(0.31-4.73)\end{array}$ \\
\hline \multicolumn{7}{|c|}{ (C) Spermatocrit (\%) ${ }^{\mathrm{a}}$} \\
\hline Control & & & & $\begin{array}{l}5.2 \\
(0.31-10.1)\end{array}$ & $\begin{array}{l}7.53 \\
(1.82-15.29)\end{array}$ & $\begin{array}{l}11.82 \\
(1.20-18.95)\end{array}$ \\
\hline $\mathrm{Sa}_{1}$ & & $\begin{array}{l}2.39 \\
(\epsilon-3.85)\end{array}$ & $\begin{array}{l}5.01 \\
(1.82-8.33)\end{array}$ & $\begin{array}{l}4.77 \\
(1.51-14.00)\end{array}$ & $\begin{array}{l}8.01 \\
(2.3-16.67)\end{array}$ & $\begin{array}{l}10.51 \\
(4.41-19.05)\end{array}$ \\
\hline $\mathrm{Sa}_{2}$ & & $\begin{array}{l}2.74 \\
(\epsilon-13.35)\end{array}$ & $\begin{array}{l}7.61 \\
(1.96-16.00)\end{array}$ & $\begin{array}{l}12.32 \\
(\epsilon-28.57)\end{array}$ & $\begin{array}{l}13.13 \\
(2.3-24.74)\end{array}$ & $\begin{array}{l}9.64 \\
(4.88-20.20)\end{array}$ \\
\hline $\mathbf{P g}$ & & $\epsilon$ & $\begin{array}{l}2.2 \\
(\epsilon-3.77)\end{array}$ & $\begin{array}{l}2.86 \\
(\epsilon-5.88)\end{array}$ & $\begin{array}{l}6.51 \\
(1.35-18.45)\end{array}$ & $\begin{array}{l}6.85 \\
(1.90-25.80)\end{array}$ \\
\hline & & $\epsilon$ & $\begin{array}{l}7.08 \\
(2.22-16.67)\end{array}$ & $\begin{array}{l}9.04 \\
(6.06-14.63)\end{array}$ & $\begin{array}{l}7.70 \\
(4.29-14.95)\end{array}$ & $\begin{array}{l}7.54 \\
(\epsilon-16.49)\end{array}$ \\
\hline $\mathrm{Ch}$ & & $\begin{array}{l}5.66 \\
(\epsilon-11.43)\end{array}$ & $\begin{array}{l}7.74 \\
(4.16-14.00)\end{array}$ & $\begin{array}{l}5.59 \\
(\epsilon-13.20)\end{array}$ & $\begin{array}{l}7.59 \\
(2.90-15.21)\end{array}$ & $\begin{array}{l}9.38 \\
(1.54-20.18)\end{array}$ \\
\hline
\end{tabular}

\footnotetext{
${ }^{a}$ Means were calculated from the number of males giving milt, and the extreme values are given in parentheses.
}

$\epsilon$ : Values too low to be determined.

$\mathrm{Sa}_{1}, \mathrm{Sa}_{2}, \mathrm{Pg}, \mathrm{Si}, \mathrm{Ch}$ : LHRHa-treated groups. See details of treatments in Materials and Methods section. 


\section{Hormonal characteristics}

(a) Plasma GtH levels (Table III)

In the controls, mean plasma GtH levels were low and constant throughout the experimental period. All five LHRHa treatments provoked a rapid rise in plasma $\mathrm{GtH}$ since by day 2 higher GtH levels were observed than in the controls $(P<0.02)$. These levels remained elevated throughout the experimental period. Plasma GtH dynamics following LHRHa administration by injection or implant seemed different. D-Ala ${ }^{6}$-LHRH EA in silicone rubber (group $\mathrm{Si}$ ) or D-Nal (2) ${ }^{6}$-LHRH in cholesterol pellet (group $\mathrm{Ch}$ ) provoked chronic increases in GtH levels from day 2 to day 12 since means are not statistically different among all the samples. However, in group $\mathrm{Ch}$, three fish out of seven showed increasing GtH levels from day 2 to day 12. On the other hand, D-Ala ${ }^{6}$-LHRH EA administered by multiple injections in saline (groups $\mathrm{Sa}_{1}$ and $\mathrm{Sa}_{2}$ ) resulted in increasing circulating plasma GtH levels from day 2 to day $12(P<0.005)$. A third GtH profile is observed after administration of the same analogue in $40 \%$ propylene glycol: the first injection on day 1 caused constant GtH levels from day 2 to day 4 , higher than those observed in the controls. The second injection on day 7 produced a transitory increase on day $8(P<0.01)$, and then the level decreased but was still higher than those observed in the control.

\section{TABLE III}

The influence of LHRHa treatments on plasma $\mathrm{GtH}(\mathrm{ng} / \mathrm{ml})$ in male landlocked salmon

\begin{tabular}{|c|c|c|c|c|c|}
\hline \multirow{2}{*}{$\begin{array}{l}\text { Treatment } \\
\text { groups }\end{array}$} & \multicolumn{5}{|c|}{ Days of experiment } \\
\hline & 2 & 4 & 8 & 10 & 12 \\
\hline Control & $1.67 \pm 0.14$ & $1.51 \pm 0.13$ & $1.36 \pm 0.07$ & $1.39 \pm 0.05$ & $0.71 \pm 0.26$ \\
\hline $\mathrm{Sa}_{1}$ & $2.86 \pm 0.37$ & $5.51 \pm 0.89$ & $8.97 \pm 0.88$ & $9.73 \pm 1.71$ & $12.91 \pm 2.28$ \\
\hline $\mathrm{Sa}_{2}$ & $3.50 \pm 0.41$ & $5.33 \pm 0.70$ & $10.53 \pm 1.80$ & $15.58 \pm 2.33$ & $16.32 \pm 2.91$ \\
\hline $\mathrm{Pg}$ & $3.18 \pm 0.16$ & $2.72 \pm 0.38$ & $8.33 \pm 0.38$ & $4.06 \pm 0.38$ & $4.28 \pm 2.27$ \\
\hline $\mathrm{Si}$ & $4.59 \pm 0.91$ & $5.82 \pm 1.47$ & $6.49 \pm 0.89$ & $5.95 \pm 0.92$ & $6.54 \pm 1.85$ \\
\hline Ch & $5.70 \pm 1.98$ & $7.6 \pm 2.15$ & $10.41 \pm 3.02$ & $10.85 \pm 2.94$ & $10.88 \pm 2.61$ \\
\hline
\end{tabular}

Values are $\bar{X} \pm$ S.E.M.

$\mathrm{Sa}_{1}, \mathrm{Sa}_{2}, \mathrm{Pg}, \mathrm{Si}, \mathrm{Ch}:$ LHRHa-treated groups. See details of treatments in Materials and Methods section.

(b) Pituitary GtH levels (Table IV)

At the end of the experiment (day 12), pituitary GtH content did not differ between LHRHa-treated and control fish.

Relation between spermiation and hormonal characteristics (Fig. 1)

The cumulative values of plasma GtH, collectable milt volume and spermatocrit, obtained by summing the values observed at each sampling from day 1 to day 12 , were compared among the different groups. In all the 


\section{TABLE IV}

The influence of LHRHa treatments on pituitary GtH content in male landlocked salmon Treatment $\quad$ GtH $(\mu \mathrm{g} / \mathrm{mg}$ pituitary per g body weight)

groups

\begin{tabular}{ll}
\hline Control & $0.059 \pm 0.02$ \\
$\mathrm{Sa}_{2}$ & $0.059 \pm 0.01$ \\
$\mathrm{Sa}_{2}$ & $0.066 \pm 0.02$ \\
$\mathrm{Pg}_{\mathrm{Si}}$ & $0.062 \pm 0.01$ \\
$\mathrm{Ch}$ & $0.089 \pm 0.02$ \\
& $0.056 \pm 0.01$
\end{tabular}

Values are $\bar{X} \pm$ S.E.M.

$\mathrm{Sa}_{1}, \mathrm{Sa}_{2}, \mathrm{Pg}, \mathrm{Si}, \mathrm{Ch}$ : LHRHa-treated groups. See details of treatments in Materials and Methods section.
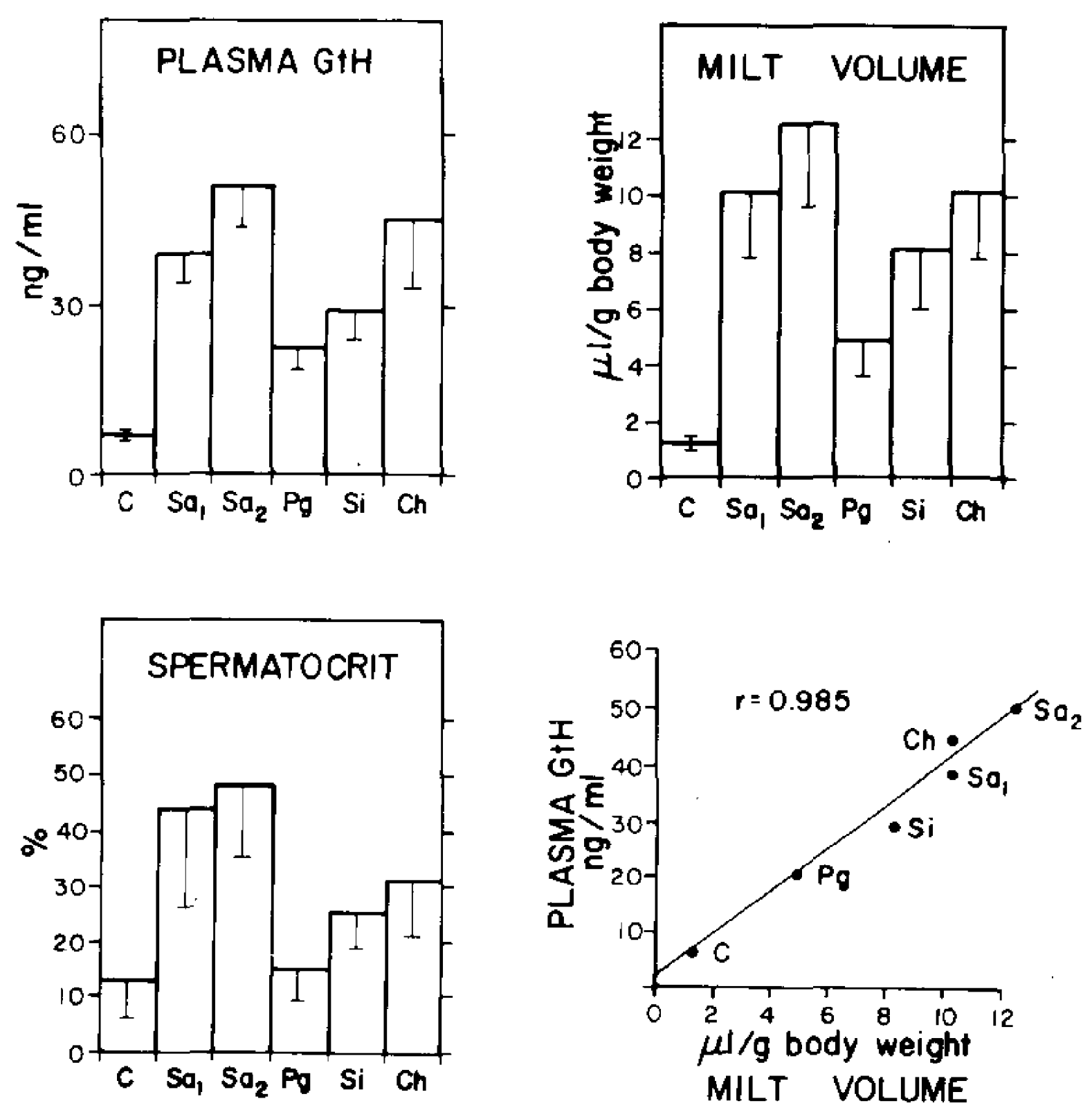

Fig. 1. The influence of LHRHa treatments on the 12-day cumulative amounts of plasma $\mathrm{GtH}$, collectable milt volume and spermatocrit in male landlocked salmon. Values are $\bar{X} \pm$ S.E.M. C = Control group. $\mathrm{Sa}_{1}, \mathrm{Sa}_{2}, \mathrm{Pg}, \mathrm{Si}, \mathrm{Ch}:$ LHRHa-treated groups. See details of treatments in Materials and Methods. 
LHRHa-treated fish, cumulative plasma $\mathrm{GtH}$ and milt volume were higher than those observed in controls $(P<0.02)$. In the LHRHa-treated fish the lowest values for these two parameters were observed when the analogue was administered in propylene glycol. A positive correlation was noticed between the volume of collected milt and plasma $\mathrm{GtH}$. In groups $\mathrm{Sa}_{1}, \mathrm{Sa}_{2}, \mathrm{Ch}$ and $\mathrm{Si}$, in which spermiation started on the same day, the total amount of collectable milt was very similar. In group $\mathrm{Pg}$, in which spermiation occurred two days later, total collectable milt was the lowest, but was only significantly different from group $\mathrm{Sa}_{2}(P<0.02)$.

Cumulative spermatocrit was not statistically different between control and LHRHa-treated fish. As the cumulative collected milt volume was higher in treated fish, this indicated that spermatozoa production had increased with sperm volume.

\section{DISCUSSION}

The present work has demonstrated that in prespawning landlocked salmon, D-Ala ${ }^{6}$-LHRH EA administered in a variety of vehicles (saline, $40 \%$ propylene glycol, silicone rubber) and D-Nal $(2)^{6}-\mathrm{LHRH}$ administered in cholesterol pellet have a positive effect on the pituitary-gonadal axis. Indeed, in comparison with the controls, the different LHRHa treatments accelerated the onset of spermiation; spermiation occurred 6 to 4 days earlier and at the end of the 12-day experimental period all the LHRHa-treated fish were spermiating whereas in the control group only $75 \%$ were spermiating. As a consequence of this acceleration, during the experimental period the different LHRHa treatments induced an increase in the total milt volume production, the highest total amounts of collected milt being obtained from the LHRHa-treated fish. As the cumulative spermatocrit is similar between LHRHa-treated and control fish, this increase in milt volume provoked by LHRH analogues is not just due to sperm dilution but is a true stimulation of spermatozoa production. In the present work, control and LHRH-treated fish were killed a short time after the beginning of spermiation, and so we cannot draw conclusions on the effect of LHRH analogues in extending the duration of spermiation and in increasing the volume of milt. However, these two parameters are increased when an LHRH analogue is administered to spermiating landlocked salmon (Crim et al. 1982). Further studies are required in prespawning fish to evaluate the effect of LHRH analogues on the acceleration and duration of spermiation and on the volume of milt produced.

LHRHa-induced spermiation and spontaneous spermiation present the same characteristics. We noticed in control and treated fish heterogeneous values for collectable milt volume and for spermatocrit. This heterogeneity in spermatocrit has already been noticed in rainbow trout at the beginning of spontaneous spermiation (Fostier et al., 1982). The difficulty of accurately measuring the volume of milt and spermiation from such small amounts of 
milt collectable at the beginning of spermiation may explain the highly variable response. Milt volume values obtained after LHRH treatments are in agreement with those noticed in rainbow trout at the beginning of spermiation (Fostier et al. 1982).

This is the first report of D-Ala ${ }^{6}$-LHRH EA and D-Nal $(2)^{6}$-LHRH advancing spermiation in salmonids. D-Ala ${ }^{6}$-LHRH EA has already been shown to increase milt volume production in prespawning black carp (Anon., 1977a) and common carp (Takashima et al., personal communication, 1981), species in which abundant milt is difficult to obtain in captivity. Another analogue, des-Gly ${ }^{10}$-DTrp ${ }^{6}$-LHRH ethylamide, administered in cholesterol pellet to prespawning landlocked salmon, one-and-a-half months earlier than we did, also induced spermiation earlier than usual (Crim et al., 1982). On the other hand, des-Gly ${ }^{10}$-DTrp ${ }^{6}$-LHRH failed to induce spermiation in prespawning northern pike (Billard and Marcel, 1980). This observation suggests that either the latter analogue is not effective, or that the way of administration (intracardiac injections in saline) or the doses used by these authors are not appropriate. The present work suggests that for a particular analogue the vehicle used may play an important role in the biological effects obtained. Indeed, we found that D-Ala ${ }^{6}$-LHRH EA administered at $0.750 \mathrm{mg} / \mathrm{kg}$ in saline by multiple injections or at $1.6 \mathrm{mg} / \mathrm{kg}$ in a single silicone rubber implant induced the beginning of spermiation 6 days earlier than in the controls whereas $0.750 \mathrm{mg} / \mathrm{kg}$ administered in $40 \%$ propylene glycol had a slower effect since the onset of spermiation occurred only 4 days earlier than in the controls.

In every case the different LHRHa treatments provoked an increase in the plasma GtH as early as $24 \mathrm{~h}$ after the beginning of the treatment, and GtH levels remained high throughout the 12-day experimental period. In contrast, in control fish plasma GtH was low and constant throughout the experimental period. In rainbow trout, it has been noticed that GtH is high at the initiation of sperm release and then decreases slowly during the first part of spermiation (Sanchez-Rodriguez et al., 1978; Fostier et al., 1982). In the present work, during the experimental period this decrease was not noticed when LHRH was administered by injection in saline or by implant. In controls, although GtH levels tended to decrease on day 12, the experiment was too short to corroborate this point in landlocked salmon.

In the present work we observed a positive correlation between the total amount of sperm collected and plasma GtH. We can classify the effectiveness of the different LHRHa treatments in the following increasing order: two injections of D-Ala ${ }^{6}$-LHRH EA in propylene glycol (total dose $0.75 \mathrm{mg} / \mathrm{kg}$ ), one single silicone rubber implant of D-Ala ${ }^{6}$-LHRH EA (total dose $1.6 \mathrm{mg} /$ $\mathrm{kg})$, six injections of D-Ala ${ }^{6}-\mathrm{LHRH}$ EA in saline $(0.75 \mathrm{mg} / \mathrm{kg})$ and one single cholesterol pellet of $\mathrm{D}-\mathrm{Nal}(2)^{6}-\mathrm{LHRH}(0.270 \mathrm{mg} / \mathrm{kg}), 12$ injections of D-Ala ${ }^{6}$-LHRH EA in saline (total dose $0.75 \mathrm{mg} / \mathrm{kg}$ ). In different salmonids spermiation is characterized by high androgen levels (review by Billard et al., 1982) and particularly in Salmo salar 11-oxotestosterone (Idler et al., 1971) 
and testosterone and 11-oxotestosterone (Hunt et al., 1982). Since, in fish, both LHRH (female common carp: Weil et al., 1980; male and female dogfish: Jenkins and Dodd, 1980) and LHRH analogue (male carp: Takashima et al., personal communication, 1981) are able to induce steroid synthesis, the highest collectable milt volumes noticed in this experiment might be related to the highest androgen levels provoked by the treatment. Furthermore, in rainbow trout, at the beginning of spontaneous spermiation, the quantities of collected sperm are positively correlated with the 11-oxotestosterone levels (Fostier et al., 1982). Further experiments are required to study such correlations in landlocked salmon treated with LHRH analogues since in the present experiment plasma samples were not large enough for studying this point.

Contrary to the positive effect of LHRHa treatments upon spermiation and plasma GtH, no effect was noticed on pituitary GtH synthesis in late prespawning landlocked salmon since GtH content was similar between control and treated fish. As pituitary samples were taken at the same time, we cannot relate this result to a possibility of a circadian rhythm of GtH synthesis. However, previous work in landlocked salmon suggests that LHRH analogues have a stimulatory effect on pituitary GtH synthesis only at an earlier stage of sexual development when pituitary GtH is low (Crim et al., 1982).

The present work represents the first demonstration in fish that silicone rubber is capable of releasing LHRH analogues over a period of at least 12 days since spermiation and plasma GtH levels are stimulated. Such an effect has been previously described for LHRH in rats (Lotz and Syllwasschy, 1979). The constant GtH levels monitored throughout the experimental period suggest that D-Ala ${ }^{6}$-LHRH EA is regularly released from the silicone rubber. In consequence, a single silicone rubber implant may be a good way to provide sustained release of LHRH and LHRH analogues. The chronic high GtH levels monitored in this experiment by means of frequent blood sampling, confirmed that LHRHa in a cholesterol pellet is able to provide prolonged releasing hormone activity as previously demonstrated in mammals (Kent et al., 1980) and fish (Crim et al., 1982). On the other hand, the transitory increase in plasma GtH noticed after the second injection of D-Ala ${ }^{6}$-LHRH EA in $40 \%$ propylene glycol suggests that this type of release is less prolonged. The increasing plasma GtH noticed from day 1 to day 12 after injection of D-Ala ${ }^{6}$-LHRH EA in saline might be explained by the fact that plasma GtH has not yet returned to basic level when each LHRH analogue injection is administered. None of the different ways of LHRH administration (multiple injections or single implant) suppressed pituitary secretion, since high plasma GtH levels were noticed throughout the experimental period. However, in goldfish a self suppression has been noted after multiple injections of LHRHa (Peter, 1980). On the other hand, we found no evidence of self potentiation as previously described in goldfish (Peter, 1980) since in our work the same dosage of D-Ala ${ }^{6}$-LHRH EA administered 
in saline by a single injection every two days (group $\mathrm{Sa}_{1}$ ) or by two injections given $6 \mathrm{~h}$ apart every two days (group $\mathrm{Sa}_{2}$ ) had the same effectiveness on plasma GtH and collected milt volume values. For such a potentiation the interval between injections and the doses used must be important (Lin et al., 1982).

The present work has demonstrated that LHRHa can be administered in a variety of vehicles to accelerate the onset of spermiation in landlocked salmon. All the methods used are effective; however, two injections in $40 \%$ propylene glycol had a slower effect than multiple injections in saline or a single implant (cholesterol or silicone rubber). However, the analogue used in the cholesterol implant is different from the other treatments. So far, no studies comparing the biological activity of these two analogues are available in fish. Such a comparative study is required in prespawning landlocked salmon.

Some effects of stress on reproduction have been reported but no results on the effect of handling and anesthesia on spermiation are available (review by Billard et al., 1981). In the present work, implanted fish had an additional stress since all the fish were anesthetized every two days. However, LHRH implantations are effective in accelerating spermiation. As a consequence, implantation methods, which eliminate the need for frequent handling of fish, seem to hold promise for inducing spermiation in species easily stressed and giving insufficient milt or undergoing milt resorption in captivity. Further experiments are required in these species to determine the appropriate schedule of application of LHRH analogues and to optimize the dosages. Furthermore, implantation methods may be useful in decreasing the costs of labor in advancing the final events of gonadal maturation and initiating spawning.

\section{ACKNOWLEDGEMENTS}

The visit of C. Weil to St John's was made possible by C.N.R.S. (France) and supported by a grant 1178/GG/81 from I.N.R.A. (France).

\section{REFERENCES}

Aida, K., Izumo, R.S., Satoh, H. and Hibiya, M., 1978. Induction of ovulation in plaice and goby with synthetic LH releasing hormone. Bull. Jpn. Soc. Sci. Fish., 44: $445-450$.

Anon., 1975. Experiments on inducement of spawning in domestic fish by injection of synthesized hypothalamic luteinizing hormone-releasing hormone ( $\mathrm{LH}-\mathrm{RH}$ ). Kexue Tongbao, 20(1): 43-48. (FMS Translation Series No. 4186.)

Anon., 1977a. A new highly effective ovulating agent for fish reproduction. Sci. Sin., 20 : $469-474$.

Anon., $1977 \mathrm{~b}$. A further investigation on the stimulatory effect of a synthetic analogue of hypothalamic luteinizing hormone releasing hormone (LHRH) on spawning in domestic fishes. Acta Biochem. Biophys. Sin., 9(1): 15-23. 
Ball, J.N., 1981. Hypothalamic control of the pars distalis in fishes, amphibians and reptiles. Gen. Comp. Endocrinol,, 44: 135-170.

Barnett, T.H., Sohn, J., Reichlin, S. and Jackson, I.M.D., 1982. Three luteinizing hormone-releasing hormone like substances in a teleost fish brain: none identical with the mammalian LH-RH decapeptide. Biochem. Biophys. Res. Commun., 105: 209216.

Billard, R. and Marcel, J., 1980. Stimulation of spermiation and induction of ovulation in pike (Esox lucius). Aquaculture, 21: 181-195.

Billard, R., Bry, C. and Gillet, C., 1981. Stress, environment and reproduction in teleost fish. In: A.D. Pickering (Editor), Stress and Fish. Academic Press London, New York, 185-208.

Billard, R., Fostier, A., Weil, C. and Breton, B., 1982. The endocrine control of spermatogenesis in teleost fish. Can. J. Fish. Aquat. Sci., 39:65-79.

Breton, B., Jalabert, B., Bieniarz, K., Sokolovska, M. and Epler, P., 1983. The effects of synthetic LH-RH and analog on plasma gonadotropin levels and maturational response to $17 \alpha$-hydroxy-20 $\beta$-dihydroprogesterone. Aquaculture, $32: 105-114$.

Crim, L.W., Watts, E.G. and Evans, D.M., 1975. The plasma gonadotropin profile during sexual maturation in a variety of salmonid fishes. Gen. Comp. Endocrinol., 27:62-70.

Crim, L.W., Evans, D.M. and Vickery, B.H., 1982. Manipulation of the seasonal reproductive cycle of the landlocked salmon (Salmo salar) by LHRH analogues administered in various stages of gonadal development. Can. J. Fish. Aquat. Sci., 40: 61-67.

Donaldson, E.M., Hunter, G.A. and Dye, H.M., 1981. Induced ovulation in coho salmon (Oncorhynchus kisutch). II. Preliminary study of the use of LH-RH and two high potency LH-RH analogues. Aquaculture, 26: 129-141.

Fostier, A., Billard, R., Breton, B., Legendre, M. and Marlot, S., 1982. Plasma 11-oxotestosterone and gonadotropin during the beginning of spermiation in rainbow trout (Salmo gairdneri R). Gen. Comp. Endocrinol., 46:428-434.

Hunt, S.M.V., Simpson, T.H. and Wright, R.S., 1982. Seasonal changes in the levels of 11 -oxotestosterone and testosterone in the serum of male salmon, Salmo salar L., and their relationship to growth and maturation cycle. J. Fish. Biol., 20: 105-119.

Idler, D.R., Horne, D.A. and Sangalang, G.B., 1971. Identification and quantification of the major androgens in testicular and peripheral plasma of Atlantic salmon (Salmo salar) during sexual maturation. Gen. Comp. Endocrinol., 16: 257-267.

Idler, D.R. and Crim, L.W., 1982. Gonadotropin releasing factor(s) (GtH-RF) from hypothalamus of winter flounder. In: B. Lofts (Editor), Proceedings of the Ninth International Symposium on Comparative Endocrinology. University of Hong Kong Press, Hong Kong, in press.

Jenkins, N. and Dodd, J.M., 1980. Effects of synthetic mammalian gonadotropin releasing hormone and dogfish hypothalamic extracts on levels of androgens and oestradiol in the circulation of the dogfish (Scyliorhinus canicula L.). J. Endocrinol., 86: 171-177.

Kent, J.S., Vickery, B.H. and McRae, G.I., 1980. The use of a cholesterol matrix pellet implant for early studies on the prolonged release in animals of agonist analogues of luteinizing hormone releasing hormone. 7th Int. Symp. Controlled Release of Bioactive Materials. Fort Lauderdale, Florida, U.S.A.

King, J.A. and Millar, R.P., 1980. Comparative aspects of luteinizing hormone releasing hormone. Structure and function in vertebrate phylogeny. Endocrinology, 106: 707-717.

Lam, T.J., Pandey, S., Nagahama, Y. and Hoar, W.S., 1976. Effect of synthetic luteinizing hormone releasing hormone (LH-RH) on ovulation and pituitary cytology of the goldfish, Carassius auratus. Can. J. Zool., 54: 816-824.

Lam, T.J., 1982. Applications of endocrinology to fish culture. Can. J. Fish. Aquat. Sci., 39: $111-137$. 
Lin, H.R., Peter, R.E., Nahorniak, C.S. and Bres, O., 1982. Actions of the superactive analogue Des-Gly ${ }^{10}\left[\mathrm{D}-\mathrm{Ala}^{6}\right]$ LHRH ethylamide (LHRH-A) on gonadotropin secretion in goldfish. In: B. Lofts (Editor), Proceedings of the Ninth International Symposium of Comparative Endocrinology. University of Hong Kong Press, Hong Kong, in press.

Lotz, W. and Syllwasschy, B., 1979. Release of oligopeptides from silicone rubber implants in rats over periods exceeding ten days. J. Pharm. Pharmacol., 31: 649-650.

Nestor, J.N., Ho, T.L., Simpson, R.A., Horner, B.L. and Jones, G.H, 1982. Synthesis and biological activity of some very hydrophobic superagonist analogues of luteinizing hormone-releasing hormone. J. Med. Chem., 25: 795-801.

Peter, R.E., 1980. Serum gonadotropin levels in mature male goldfish in response to luteinizing hormone releasing hormone (LH-RH) and des-Gly ${ }^{10}$ [D-Ala ${ }^{6}$ ]-LHRH ethylamide. Can. J. Zool., 58: 1100-1104.

Sanchez-Rodriguez, M., Escaffre, A.M., Marlot, S. and Reinaud, P., 1978. The spermiation period in the rainbow trout (Salmo gairdneri). Plasma gonadotropin and an. drogen levels, sperm production and biochemical changes in the seminal fluid. Ann. Biol. Anim. Biochim. Biophys., 18: 943-948.

Sokolowska, M, Popek, W. and Bieniarz, K., 1978. Synthetic releasing hormones LH/ FSH-RH and LH-RH - effect of intracerebral and intramuscular injections on female carp (Cyprinus carpio L.) maturation. Ann. Biol. Anim. Biochim. Biophys., 18: 963-975.

Van Der Kraak, G., Lin, H.R., Donaldson, E.M., Dye, H.M. and Hunter, G.A., 1982. Effects of LH-RH and des-Gly ${ }^{10}$ [D-Ala ${ }^{6}$ ] LH-RH-ethylamide on plasma gonadotropin levels and oocyte maturation in adult female coho salmon (Oncorhynchus kisutch). Gen. Comp. Endocrinol., 49: 470-476.

Weil, C., Fostier, A., Horvath, L. and Marlot, S , 1980. Profiles of plasma gonadotropin and $17 \beta$ estradiol in the common carp, Cyprinus carpio L., as related to spawning induced by hypophysation or LHRH treatment. Reprod. Nutr. Dev., 20: 1041-1050.

Wolf, K., 1963. Physiological salines for freshwater teleosts. Prog. Fish. Cult., 15: 135140. 